\title{
Zebra Finch Neoplasm
}

National Cancer Institute

\section{Source}

National Cancer Institute. Zebra Finch Neoplasm. NCI Thesaurus. Code C134785.

A neoplasm that occurs in a zebra finch. 